\title{
An insight into low contraceptive prevalence in Malaysia and its probable consequences
}

\author{
Mohamed Najimudeen*, Kanagasabai Sachchithanantham
}

Department of Obstetrics \& Gynaecology, Melaka Manipal Medical College, Melaka, Malaysia

Received: 30 June 2014

Accepted: 13 July 2014

\section{*Correspondence:}

Dr. Mohamed Najimudeen,

E-mail: najim5543@yahoo.com

(C) 2014 Najimudeen $\mathrm{M}$ et al. This is an open-access article distributed under the terms of the Creative Commons Attribution Non-Commercial License, which permits unrestricted non-commercial use, distribution, and reproduction in any medium, provided the original work is properly cited.

\begin{abstract}
The Contraceptive Prevalence Rate (CPR) in Malaysia for all methods is 55\% and for modern methods is $35 \%$. These figures are very low compared to neighbour countries. This analysis is to find the probable reasons and suggest remedies for the very low contraceptive use and minimize the adverse consequences. This is a retrospective analysis based on the reports of National Population and Family Development Board (NPFDB) and Ministry of Health Malaysia from 1974 to 2012 . There is no difference in the use of contraception between the different ethnic groups. The unmet contraceptive demand is $25 \%$. In a study of teenagers between the ages of $18-21$, around $20 \%$ had sex with new partners without using any contraceptive methods. Of the 510462 babies born in the year 2010, there were 52982 out of wedlock pregnancies. These mothers had not used any form of contraceptives. The contraceptive use in Malaysia had stagnated for 25 years. Approximately $60 \%$ of these mothers had not used any form of contraception. Lack of contraceptive awareness; myths and non-availability are possibly the major causes for less use of contraceptives. Family planning services must be free and freely available in urban as well as rural areas.
\end{abstract}

Keywords: Contraceptive prevalence rate, Unmet demand, Contraception, Malaysia

\section{INTRODUCTION}

Contraceptive prevalence rate is the percentage of women who are practicing, or whose sexual partners are practicing, any form of contraception.

It is usually measured for married women between the ages of 15-49 only.

The Contraceptive Prevalence Rate (CPR) in Malaysia for all the available methods is $55 \%$ and for modern methods is $32 \%$.

The CPR is much lower as compared to global rate and lesser than the neighbour countries.
Table 1: Contraceptive prevalence rate in some countries (2005-2010). ${ }^{1}$ Low contraceptive prevalence in Malaysia.

\begin{tabular}{|ll|}
\hline \multicolumn{2}{|l|}{ Contraceptive prevalence rate } \\
\hline Global rate & $63.0 \%$ \\
\hline Portugal & $86.8 \%$ \\
\hline United Kingdom & $84.0 \%$ \\
\hline U S A & $78.6 \%$ \\
\hline Thailand & $77.5 \%$ \\
\hline Sri Lanka & $68.3 \%$ \\
\hline Singapore & $55.1 \%$ \\
\hline Malaysia & $\mathbf{3 2 . 3 \%}$ \\
\hline
\end{tabular}




\section{METHODS}

This is the retrospective analysis based on the reports of National Population and Family Development Board (NPFDB) and ministry of health Malaysia as mentioned in the references list.

\section{DISCUSSION}

The current population of Malaysia is approximately 28 million. There are approximately 520000 babies born each year. There is no difference in the use of contraception between the different ethnic groups. The unmet contraceptive is $25 \%$.

The CPR is lowest in the most vulnerable group of 15-19 years. This is one of reason for the increased incidence of teenage pregnancies. Around $20 \%$ of the married couple have not used any contraceptive methods at all.

The contraceptive use in Malaysia had stagnated for 25 years now, while its unmet need for family planning remains high and is increasing resulting in unplanned pregnancies and unwanted births, especially for women with less education. This is another area in which Malaysia, on current trends, will not be able to meet the MDG goals by $2015 .^{2}$

Table 2: CPR by methods in Malaysia. ${ }^{3}$ CPR has not significantly increased over 30 years.

\begin{tabular}{|lllll|}
\hline Method & $\mathbf{1 9 7 4}$ & $\mathbf{1 9 8 4}$ & $\mathbf{1 9 9 4}$ & $\mathbf{2 0 0 4}$ \\
\hline CPR & $26.0 \%$ & $28.4 \%$ & $30.2 \%$ & $33.9 \%$ \\
\hline OCP & 18.0 & 11.9 & 13.3 & 14.0 \\
\hline Depo Provera & 0.2 & 0.5 & 0.6 & 1.3 \\
\hline IUCD & 0.8 & 2.2 & 3.9 & 4.5 \\
\hline Condom & 3.2 & 7.7 & 5.4 & 7.4 \\
\hline F/sterilize & 3.8 & 7.6 & 6.9 & 6.6 \\
\hline Vasectomy & 0.0 & 0.2 & 0.1 & 0.1 \\
\hline
\end{tabular}

The Table 2 shows that the contraceptive prevalence rate in the year 1974 was $26.0 \%$ and it has moved only to $33.9 \%$ over 30 years. The female surgical sterilization has doubled in 30 years. The IUCD has become popular but other long term contraceptives like implanon has not reached the population. The implanon insertion is not freely available in the government hospitals and it costs about RM 500 (USD 166) in private sector. This is considerably expensive for low socio-economic group. Unlike female surgical methods, vasectomy is a simple procedure. However it is not many popular in many countries in the East Asia.

\section{Unmet demand}

Unmet demand is the gap between not wanting another child at time of interview and not using contraception

According to 2004 demographic survey, ${ }^{3}$ around $25 \%$ of women said they did not want another child but were not using contraception This is the case of married women. Most of the unmarried women obviously do not want a baby. In fact the unmet need for contraception is much higher than $25 \%$.

Table 3: Similarity of unmet among different ethnicities.

\begin{tabular}{|lll|}
\hline Ethnicity & CPR & $\begin{array}{l}\text { Unmet } \\
\text { demand }\end{array}$ \\
\hline Malays & $39.3 \%$ & $25.9 \%$ \\
\hline Chinese & $64.3 \%$ & $22.2 \%$ \\
\hline Indians & $51.0 \%$ & $26.6 \%$ \\
\hline
\end{tabular}

Table 3 shows that there is no different in unmet demand among different ethnic group.

Table 4: Reflecting the difference between Urban and rural setups.

\begin{tabular}{|lll|}
\hline State & CPR & $\begin{array}{l}\text { Unmet } \\
\text { demand }\end{array}$ \\
\hline Negeri Sembilan & $63 \%$ & $14.9 \%$ \\
\hline Melaka & $54 \%$ & $24.8 \%$ \\
\hline Penang & $44.8 \%$ & $30.3 \%$ \\
\hline Kedah & $43 \%$ & $20.3 \%$ \\
\hline Terengganu & $29.9 \%$ & $25.1 \%$ \\
\hline Kelantan & $24.3 \%$ & $33.3 \%$ \\
\hline
\end{tabular}

Table 4 shows that there is a significant different between the rural population, educational standard, social background in the use of contraceptive use. Negeri Sembilan is the Kuala Lumpur capital city area. The CPR is very high and the unmet demand is very low. Kuantan area is relatively a rural area. The CPR is low and the unmet demand in high. The contraceptive uses differ accordingly in different states of Malaysia.

Table 5: Reasons for not using/discontinuing contraceptive methods. ${ }^{4}$

\begin{tabular}{|ll|l|}
\hline Reasons & 1994 & 2004 \\
\hline Want of child & $53.0 \%$ & $39.3 \%$ \\
\hline Husband's objection & 8.0 & 12.6 \\
\hline Medical reasons & 3.3 & 5.4 \\
\hline Fear of side effects & 10.3 & 26.8 \\
\hline No reasons & 25.4 & 15.9 \\
\hline
\end{tabular}

Table 5 shows that fear of side effects and no reasons contribute about $35-40 \%$. The health education is necessary to alleviate the fear of contraceptives and to educate the advantages of contraceptive methods

Global sex survey 2009 was the 15 minutes online study with young people around the world on sex and contraception. ${ }^{5}$ The study period was from 15.07.2009 to 3.08.2009 among teenagers between 18-21 years. In Malaysia 101 males and 100 females participated in this study. Some of the findings are: 
Table 6: Sex and contraception. Sex with new partner without using contraception.

\begin{tabular}{|ll|}
\hline Country & Percentage \\
\hline Malaysia & $17 \%$ \\
\hline Singapore & $11 \%$ \\
\hline Korea & $06 \%$ \\
\hline
\end{tabular}

Other findings of this study about Malaysian youths were:

- About $20 \%$ have had sex with a new partner without using contraception;

- More than $20 \%$ of females did not use contraception because they did not like it;

- About $20 \%$ females did not use contraception because their partner preferred them not to;

- About $20 \%$ had sought contraception advice on the internet;

- $\quad 59 \%$ would like to consult someone in confidence;

- $57 \%$ thought that sex education in school could be improved; and

- $91 \%$ thought that the condom is an effective contraceptive method.

\section{Consequences of low contraceptive prevalence}

Out of wedlock babies

The most important reason for out of wedlock pregnancies in Malaysia was the non-use of contraceptive methods.

Table 7: Out of wedlock babies.

\begin{tabular}{|lll|}
\hline Year & $\begin{array}{l}\text { No. of out } \\
\text { of wedlock } \\
\text { pregnancies }\end{array}$ & Total no. of births \\
\hline 2006 & 38258 & 472983 births \\
\hline 2007 & 44234 & 484722 \\
\hline 2008 & 46822 & 496114 \\
\hline 2009 & 52378 & 516645 \\
\hline 2010 & 52982 & 510462 \\
\hline Total & 234674 & 2480926 \\
\hline
\end{tabular}

Around 2.5 million babies are born in 5 years time and out of that 234674 babies $(9.45 \%)$ babies are out of wedlock babies. ${ }^{7}$

Most of them are very young mothers and they did not practice any contraceptive methods.

Considerable number of out of wedlock pregnancies results in abandoned babies.

The social welfare department recovered 315 discarded babies between the years of 2001 to 2005. The Police department reports an average 100 babies are thrown out annually.

\section{How to improve the situation?}

\section{Comprehensive sexuality education}

Comprehensive sexuality education has been defined as "a life-long process of acquiring information and forming attitudes, beliefs, and values about identity, relationships, and intimacy". (SIECUS 2004) It seeks to provide young people with the knowledge and skills so that they can make decisions about their health and sexuality. Contrary to perceptions, it is not just about abstinence - neither does it attempt to undermine traditional family values. It helps young people identify their personal values and increase awareness of all the choices available to them so that they can make decisions appropriate to their needs.

The ministry of education has developed several modules to educate secondary students on sexual and reproductive health under the family health education curriculum, which was launched by the ministry of education in 1989 . The topics include sexuality, gender, sexually transmitted infections and HIV/AIDS. Two periods a week are allocated, and the subjects are taught across the curriculum.

Curriculum development centre of the ministry of education again in the year 1995 introduced human body family health religious and moral value.

Unfortunately it has not given the expected results. Either the curriculum is weak, teachers are embarrassed to discuss or both could be reason for failure. Various programmes such as PROSTAR (National radio broadcasting programme) and the national service offer excellent opportunities in this area. Pilot projects like Cafe@teen implemented by the national population and family development board, as well as the HIV education programmes of the federation of family planning associations, Malaysia. Hope these can be used to reach out to more young people.

School based teaching on reproductive health improves the awareness of risk of unprotected sex in early stages of life. Early childhood interventions and youth development programmes are effective and appropriate strategies for reducing unintended teenage pregnancy rates. ${ }^{8}$

Does the religion a barrier for the use of contraceptive methods?

Around 55\% of the population in Malaysia are Muslims. Is the religion a barrier to practice contraceptive methods? Fatwa (The Islamic ruling) on contraception allows the Muslims to follow contraceptive advice on the following circumstances. ${ }^{9}$

Harus - use of contraceptives for married couples

Rape victims

OKU (mental retardation)

Unmarried couple: as emergency contraception 
There are no religious restrictions for Muslims to use contraception. There is not a single text in the Holy Quran to prevent family planning. ${ }^{10}$ Prophet Mohamed had never prohibited family planning. It is sad that the Islam is misunderstood even among Muslims.

Activities of governmental and non-governmental organizations

Family planning activities in Malaysia:

The legislators are making genuine efforts to improve the family planning services in Malaysia. The first Family Planning Association (FPA) was started in Selangor state in 1953. Thereafter 3 other states had organised FPA. This resulted in the formation of Federation of Family Planning Associations of Malaysia (FPAM) in 1958.

Family planning act was enacted in 1966 - National family planning board was formed. This was renamed as National Population and Family Development Board (NPFDB) in 1988. The family planning activities very intensified. Ministry of health and many nongovernmental organizations directly involved in family planning.

\section{CONCLUSION}

To improve the contraceptive prevalent in Malaysia, the family planning services must be free and freely available through government hospital, medical clinics in the urban as well as rural areas. Logistics should be improved in funding, manpower and training to provide effective service throughout the country. Legislators, religious leaders, non-governmental organisations and community leaders should involve to overcome social and cultural barriers. Effective health education programme on contraceptives to reach the teenagers and all males and females of childbearing age.

Funding: No funding sources Conflict of interest: None declared Ethical approval: Not required

\section{REFERENCES}

1. Leontine Alkema, Vladimira Kantorova, Clare Menozzi. National, regional, and global rates and trends in contraceptive prevalence and unmet need for family planning between 1990 and 2015: a systematic and comprehensive analysis. Lancet.2013;381(9878):1642-52.

2. Kamal Malhotra. Speech of UN Resident Coordinator, Malaysia. In: Kamal Malhotra, eds. MDG Report. Putrajaya, Malaysia: The Millennium Development Goals Report at 2010; 2011: 1-8.

3. Norliza A. Status of family planning in Malaysia (2010). In: Norliza A, eds. Family Planning in Asia and Pacific Region. Bangkok, Thailand: National Population and Family Development Board (NPFDB); 2010: 1-29.

4. Julie DaVanzo, Determinants of contraceptive choice in Malaysia. Rand Note. 1986:32.

5. National Population and Family Development Board (NPFDB). Malaysian population and family survey1994 and 2004, 2014. Available at: http://www.lppkn.gov.my/index.php?option=com_co ntent $\&$ view $=$ article $\&$ id= $211 \&$ Itemid $=787 \&$ lang=en .

6. Bayer Schering Pharma. Talking sex and contraceptive survey. TNS Health care. 2009. Available at: https://www.bayerpharma.com.

7. Milton Lum. The Star on line, 2009. Available at: http://www.thestar.com.my/Authors/?q=\%22Dr+Milt on+Lum\%22. Accessed 13 December 2009.

8. Harden A, Brunton G, Fletcher A, Oakley A. Teenage pregnancy and social disadvantage: systematic review integrating controlled trials and qualitative studies. Br Med J. 2009;339:b4254.

9. Muzakarah JWK Fatwa Kebangsaan bagi Hal Ehwal Islam Malaysia Ke 90 pada 1 Mac 2010.

10. Najimudeen M. Islam and family planning, 2000. Available at: http://aydnajimudeen.blogspot.in/.

DOI: $10.5455 / 2320-1770 . i j r \operatorname{cog} 20140943$

Cite this article as: Najimudeen $M$, Sachchithanantham

$\mathrm{K}$. An insight into low contraceptive prevalence in

Malaysia and its probable consequences. Int J Reprod

Contracept Obstet Gynecol 2014;3:493-6. 